\title{
Tumor surveillance via the ARF-p53 pathway
}

\author{
CharlesJ. Sher ${ }^{1}$ \\ Howard Hughes Medical Institute, Department of Tumor Cell Biology, St. Jude Children's Research Hospital, \\ Memphis, Tennessee 38105 USA
}

The retinoblastoma $(\mathrm{Rb})$ and $\mathrm{p} 53$ genes are not essential for completion of the cell division cycle, but disruption of their functions is central to the life history of most, if not all, cancer cells (for review, see Weinberg 1995; Sherr 1996; Levine 1997). Surprisingly, Rb and p53 are themselves regulated by two proteins encoded by a single genetic locus, INK4a/ARF, the products of which, p16 ${ }^{\mathrm{IN} \mathrm{K4a}}$ and p19ARF, are al so potent tumor suppressors. The role of $\mathrm{p} 16^{\mathrm{INK}} 4 \mathrm{a}$ as an inhibitor of cyclin D-dependent kinases has been appreciated since its discovery (Serrano et al. 1993). N ow, emerging evidence is providing valuable insights into the molecular circuitry through which p19ARF modulates p53 activity as part of a checkpoint response to oncogenic, hyperproliferative signals.

\section{Regulation of cell cycle progression by pRb and p53}

During most of $G_{1}$ phase of the mammalian cell cycle, $\mathrm{Rb}$ in its hypophosphorylated form binds to several transcription factors of the E2F family, constraining their activity on some promoters and actively repressing transcription from others (see Dyson 1998). Phosphorylation of $\mathrm{Rb}$ by cyclin-dependent kinases (cdks) in the mid-tolate $G_{1}$ phase of the cycle untethers Rb from the E2Fs. In turn, this enables the E2Fs to activate a series of target genes, the expression of which is required for cells to enter S phase, thereby stimulating proliferation (Fig. 1). The cyclin D-dependent kinases cdk4 and cdk6 trigger Rb phosphorylation, which is likely completed by cyclin E-cdk2 as cells approach the $\mathrm{G}_{1}$-to-S phase transition. Because induction and assembly of cyclin D-dependent kinases is dependent on mitogenic signaling, cancellation of Rb's growth-suppressive activity is coupled to extracellular stimuli. By inhibiting cdk4 and cdk6, a family of INK4 proteins can prevent cells with functional $\mathrm{Rb}$ from entering $\mathrm{S}$ phase. The prototypic member, p16 ${ }^{\text {IN K4a }}$ (Serrano et al. 1993), is distinguished from its close relatives $\left(\mathrm{p} 15^{\mathrm{INK} 4 \mathrm{~b}}, \mathrm{p} 18^{\mathrm{INK} 4 \mathrm{c}}\right.$, and $\left.\mathrm{p} 19^{\mathrm{INK} 4 \mathrm{~d}}\right)$ in its role as a potent tumor suppressor. Disruption of the p16 IN K4a-cyclin D1/cdk4-Rb pathway is a common event in human cancer, either resulting from loss of

IE-MAIL sher@stjudeorg, FAX (901) 495-2381. function of one of the two negative regulators ( $p 16^{\text {IN K4a }}$ or $\mathrm{Rb}$ ) or from events leading to overexpression of one of the two proto-oncogenes (cyclin D1 or cdk4) (for review, see Weinberg 1995; Sherr 1996; Ruas and Peters 1998).

The p53 protein is a transcription factor that can inhibit cell cycle progression or induce apoptosis in response to stress or DN A damage, and inactivation of p53 attenuates both of these cellular responses (for review, see Ko and Prives 1996; Levine 1997; Giaccia and Kastan 1998). Elimination of functional p53 through various mechanisms is the single most common event in human cancer, occurring in over half of all tumors (Hollstein et al. 1994). The p53 protein is short-lived and expressed at very low levels in normal cells but it is stabilized and accumulates in cells that have sustained genotoxic damage (Fig. 1). Among the gene products induced by p53 is

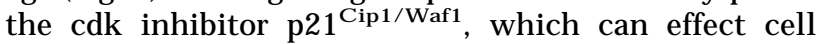
cycle arrest (El-Deiry et al. 1993; Harper et al. 1993; Xiong et al. 1993). Another key target is $\mathrm{Mdm} 2$, which acts in a feedback loop to limit the action of p53 (Barak et al. 1993; Wu et al. 1993), both by inhibiting its transactivating activity and by catalyzing its destruction (Haupt et al. 1997; Honda et al. 1997; Kubbutat et al. 1997). Mutation of p53 compromises cell cycle arrest, attenuates apoptosis induced by DNA damage, predisposes cells to drug-induced gene amplification, affects centrosome duplication, and rapidly leads to changes in chromosome number and ploidy (Kastan et al. 1991, 1992; Kuerbitz et al . 1992; Li vingstone et al. 1992; Y in et al. 1992; Clarke et al. 1993; Lowe and Ruley 1993; Lowe et al. 1993; Fukusawa et al. 1996; Jacks and Weinberg 1996; Hermeking et al. 1997; Paulovich et al. 1997; Gual berto et al. 1998; Lanni and Jacks 1998). The resulting genomic instability greatly increases the probability that p53-null cells will evolve toward malignancy.

Cooperation between the $\mathrm{Rb}$ and p53 pathways has been amply demonstrated. Classic examples involve oncoproteins encoded by the DNA tumor viruses, which both cancel $\mathrm{Rb}$ function to drive cells into $\mathrm{S}$ phase and neutralize p53 to prevent host cell suicide (for review, see White 1996). Loss of function by $\mathrm{Rb}$ and related family members can bypass p53-mediated $\mathrm{G}_{1}$ arrest (Demers et al. 1994; Slebos et al. 1994), but Rb loss induces E2F and p53-dependent apoptosis (Lowe and Ruley 1993; Howes et al. 1994; Morgenbesser et al. 1994; Pan and 


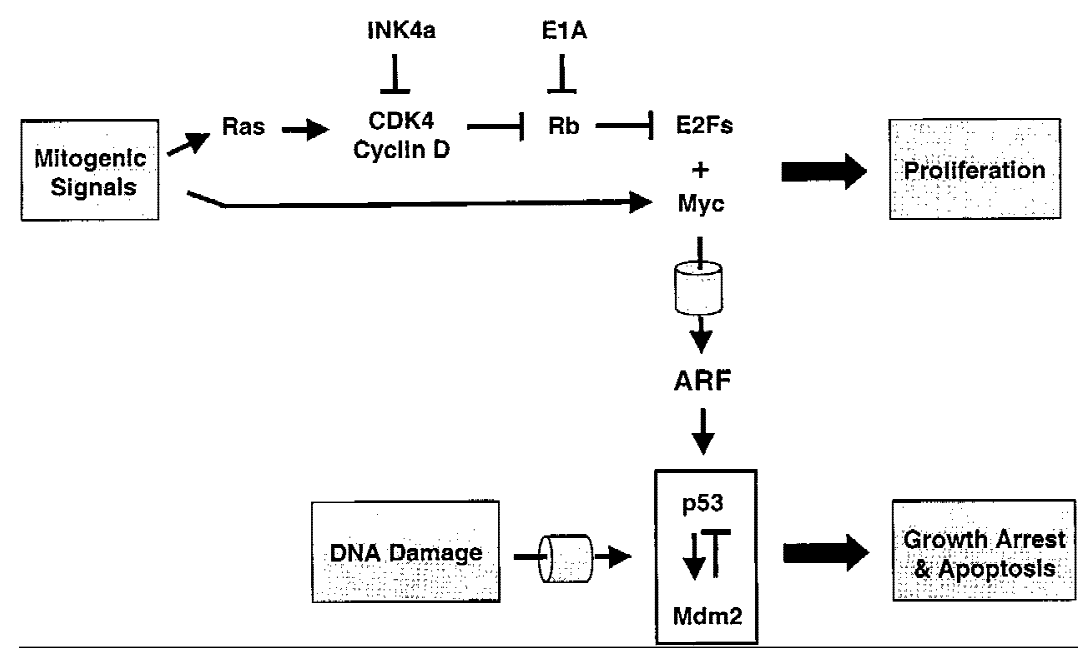

Figure 1. ARF checkpoint control. ARF responds to proliferative signals that are normally required for cell proliferation. When these signals exceed a critical threshold, the ARF-dependent checkpoint (gray vertical barrel) is activated, and ARF triggers a p53-dependent response that induces growth arrest and/ or apoptosis. Signals now known to induce signaling via the ARF-p53 pathway include Myc, $\mathrm{E} 1 \mathrm{~A}$, and E2F-1. In principle, 'upstream' oncoproteins, such as products of mutated Ras alleles, constitutively activated receptors, or cytoplasmic signal transducing oncoproteins, might also trigger ARF activity via the cyclin Dcdk4-Rb-E2F or Myc-dependent pathways, both of which are normally necessary for Sphase entry. In inhibiting cyclin D-dependent kinases, p16 ${ }^{\mathrm{INK} 4 a}$ can dampen the activity of mitogenic signals. ElA is shown to work, at least in part, by canceling $\mathrm{Rb}$ function, although its ability to inhibit p300 contributes to the response by interfering with mdm2 expression. A gain for simplicity, Myc and E2F-1 are only shown to activate p53 via ARF. However, highly overexpressed levels of these proteins can activate p53 in ARF-negative cells, albeit with an attenuated efficiency. ARF activation of p53 likely depends on inactivation of some M dm2-specific function (implied by the unfilled box bracketing the latter two proteins). DN A damage signals (ionizing and UV radiation, hypoxic stress, genotoxic drugs, etc.) access p53 through multiple signaling pathways shown, again for simplicity, as a single DNA damage checkpoint (gray horizontal barrel). Signals through the ARF and DNA damage pathways can synergize in activating p53.

Griep 1994; Qin et al. 1994; Shan et al. 1994; Symonds et al. 1994; Wu and Levine 1994). In short, mutational events that disable the p16 IN K4a-cyclin D1/cdk4-Rb pathway and enforce cell proliferation are counterbalanced by a p53-dependent apoptotic response that can eliminate incipient cancer cells. The ability of E2F to trigger p53-dependent cell suicide implies that a biochemical connection links their functions. Other cellular oncogenes, such as myc, also induce p53-dependent apoptosis (Hermeking and Eick 1994; Wagner et al. 1994). Hence, p53 is not only activated by DN A damage, but it provides an 'oncogene checkpoint' function that guards cells against hyperproliferative signals (for review, see Van Dyke 1994; Jacks and Weinberg 1996; White 1996; Levine 1997). This is the setting in which p19ARF plays a key role.

\section{The IN K 4a/ARF locus and tumor suppression}

The manner by which a single genetic locus encodes both $\mathrm{p} 16^{\mathrm{INK} 4 \mathrm{a}}$ and $\mathrm{p} 19^{\mathrm{ARF}}$ is unprecedented in mammals (Quelle et al. 1995) (Fig. 2). p16 ${ }^{\mathrm{IN} \mathrm{K4a}}$ is encoded by three closely linked exons (designated $1 \alpha, 2$, and 3). An RN A segment arising from an alternative first exon (1 $\beta)$, which maps $13-20 \mathrm{~kb}$ upstream in the human, mouse, and rat genomes, is spliced to exon 2 , yiel ding a $\beta$ transcript that is al most identical in size to the $\alpha$ transcript that encodes p16 $6^{\text {IN K4a }}$ (Duro et al. 1995; M ao et al. 1995; Quelle et al . 1995; Stone et al. 1995; Swafford et al . 1997). The initiator codon in exon $1 \beta$ is not in frame with sequences encoding $p 16^{1 \mathrm{NK} 4 \mathrm{a}}$ in exon 2 , so the $\beta$ transcript specifies a novel polypeptide. In the mouse, this 19-kD protein consists of 65 amino acids encoded by exon $1 \beta$, and 105 amino acids arising from the al ternative reading frame (ARF) of exon 2 (Quelle et al. 1995). The human protein terminates farther upstream in exon 2 and it has a predicted mol ecular mass of only $14 \mathrm{kD}$. M ouse p19ARF and human $\mathrm{p} 14^{\mathrm{ARF}}$ are highly basic nuclear proteins that induce $G_{1}$ - and $G_{2}$-phase arrest when introduced into a variety of different cell types (Quelle et al. 1995; Stott et al. 1998). INK4a/ARF-null cells are susceptible to ARFinduced arrest, so this activity of p19 ${ }^{A R F}$ does not depend upon p16 IN K4a.

Mutations that inactivate the cdk inhibitory function of $\mathrm{p} 16^{\mathrm{INK} 4 \mathrm{a}}$ occur frequently in a wide spectrum of human cancers (for review, see Ruas and Peters 1998). For example, certain inactivating point mutations impinge on exon $1 \alpha$, some of which are inherited in melanoma kindreds (Kamb et al. 1994a,b; Gruis et al. 1995). Although many point mutations in exon 2 of INK4a are also predicted to alter p19ARF, those that have been tested experimentally have been found to inactivate p16 $6^{\mathrm{INK}} 4 \mathrm{a}$ without affecting the ability of p19ARF to induce cell cycle arrest. Moreover, the amino-terminal moiety of ARF (amino acids 1-64), encoded entirely by exon $1 \beta$, is sufficient to induce cell cycle arrest when overexpressed (Quelle et al. 1997; Zhang et al. 1998), although tumor-specific point mutations in this domain have not been described (Stone et al. 1995; Ruas and Peters 1998). Together, these data suggest that $\mathrm{p} 16^{\mathrm{IN} \mathrm{K} 4 a}$ is disrupted frequently by point mutations in human cancer, but p19ARF is not. However, the common occurrence of homozygous del etions of INK4a/ARF in a wide range of human tumors leaves open the possibility that ARF plays an independent role as a tumor suppressor (see below).

Functional ablation of INK4a/ARF in mice by elimination of exons 2 and 3 (Fig. 2) revealed that derived 


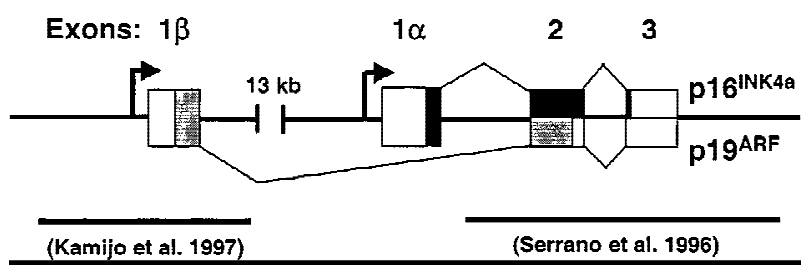

Figure 2. The INK4a/ARF locus. Genomic sequences encoding $\mathrm{p} 16^{\mathrm{INK} 4 \mathrm{a}}$ are defined by completely filled regions within the boxes designating exons $1 \alpha, 2$, and 3 , whereas the segments of exons $1 \beta$ and 2 that encode ARF are defined by shaded areas. Unfilled portions of the exons correspond to noncoding $5^{\prime}$ and $3^{\prime}$ regions. Splicing between the exons is indicated by the connecting lines, and exons $1 \alpha$ and $1 \beta$ are indicated to have separate promoters $(\rightarrow)$. In the mouse genome, the alternative first exons are separated by $\sim 13 \mathrm{~kb}$ of intervening sequences. Segments of the genes that were disrupted by Serrano et al . (1996) and Kamijo et al. (1997) are designated by horizontal lines below the schematic.

nullizygous animals were highly prone to tumor development (Serrano et al. 1996). Tumors arose early in life, and their appearance was accelerated by irradiation of newborn mice or by their treatment with chemical carcinogens. Intriguingly, mouse embryo fibrobl asts (MEFs) explanted from the INK4a/ARF knock-out mice did not undergo replicative senescence in culture. Like many established mouse cell lines, but unlike normal primary MEFs, they could be transformed by oncogenic ras alleles without a requirement for so-called immortalizing oncogenes such as myc or adenovirus ElA. M EFs from p53-null mice exhibit similar properties (Harvey et al. 1993), and p53-inactivating mutati ons are the most common single events in the spontaneous conversion of MEF strains into continuously growing cell lines (Harvey and Levine 1991). Results with both I NK4a/ARF-null or p53null MEFs directly contrast with those obtained with normal primary MEF strains, in which introduction of oncogenic ras instead provokes a state of growth arrest resembling senescence, associated with accumulation of both p53 and p16 ${ }^{\text {IN K4a }}$ (Serrano et al. 1997). Initially, it was reasoned that the phenotype observed in INK4a/ ARF-null mice depended on the loss of p16 ${ }^{\text {IN K } 4 a}$ function (Serrano et al. 1996). It followed that both $\mathrm{p} 16^{\mathrm{INK} K \mathrm{a}}$ and p53 acted as determinants of cell senescence in MEFs, with the loss of either leading to establ ishment and immortalization. Release of the senescence block by disruption of $\mathrm{p} 16^{\mathrm{INK} 4 \mathrm{a}}$ or $\mathrm{p} 53$ would be necessary for transformation of mouse fibrobl asts by oncogenic ras (Serrano et al. 1997; for review, see Weinberg 1997). A persistent ambiguity is whether these mice lack ARF function completely. This is likely, because the targeting cassette disrupted the mRNA polyadenylation signals as well as the INK4a and ARF carboxy-terminal coding equences (Fig. 2). However, the issue formally remains unresolved, because it is conceivable that a truncated ARF protein might somehow arise from undisrupted exon $1 \beta$.

Surprisingly, when pure ARF-null mice were created that lacked only the exon $1 \beta$ sequences (Fig. 2), their phenotype was indistinguishable from that attributed previously to p16 IN K4a disruption (Kamijo et al. 1997). Importantly, functional p16 $6^{\mathrm{INK} 4 \mathrm{a}}$ was expressed in normal tissues of ARF-null mice, in cultured MEFs, and in cells from spontaneously arising tumors. Therefore, ARF functions as a bona fide tumor suppressor, and the phenotype initially ascribed to INK4a loss is instead likely due to ARF inactivation. In turn, the phenotypic consequences of p16 ${ }^{\mathrm{INK} K a}$ loss in mice remain uncertain, and construction of a pure INK4a knockout strain is warranted.

\section{The ARF-p53 pathway}

A cardinal feature of ARF-null MEFs is their capacity to grow as established cell lines and to be transformed by oncogenic ras genes al one (Kamijo et al. 1997). A pproximately $20 \%$ of spontaneously established fibrobl ast cell lines derived from MEFs of wild-type mice undergo biallelic ARF loss. MEF strains that are hemizygous for ARF lose their remaining functional ARF allele and spontaneously immortalize at a faster rate than wildtype strains. In each case, established MEF cell lines that lacked ARF preserved p53 function, whereas those that retained ARF had sustained p53 mutations. These re sults suggested that $\mathrm{p} 19^{\mathrm{ARF}}$ and $\mathrm{p} 53$ might function in the same biochemical pathway. Consistent with this hypothesis, cells lacking a functional p53 gene are resistant to $\mathrm{p} 19^{\mathrm{ARF}}$-induced cell cycle arrest, implying that p53 acts downstream of ARF (Kamijo et al. 1997). However, ARF-null cells exhibit an intact p53 checkpoint following ionizing or UV irradiation, so $\mathrm{p} 19^{\mathrm{ARF}}$ does not relay signals to p53 in response to DN A damage (Fig. 1). Loss of p53 can occur in cancer cells that arise in ARF-null mice, again indicating that ARF plays a more specialized role in tumor suppression than p53, and that selection against p53 can further contribute to malignancy ( $\mathrm{Ka}$ mijo et al. 1997).

Evidence supporting direct biochemical interactions between $\mathrm{p} 19^{\mathrm{ARF}}$ and $\mathrm{p} 53$ is now in hand. Ectopic ARF expression stabilizes p53 and induces p53-responsive genes, $\mathrm{Mdm} 2$ among them. ARF can physically interact with $\mathrm{M} \mathrm{dm2}$, and its binding blocks both $\mathrm{Mdm}$ 2-induced p53 degradation and transactivational silencing (Kamijo et al. 1998; Pomerantz et al. 1998; Stott et al. 1998; Zhang et al. 1998). The interaction between $\mathrm{Mdm} 2$ and p19ARF depends on the carboxy-terminal half of $\mathrm{Mdm} 2$ and on the ARF amino-terminus (i.e., the active exon 1ß-coded segment) (Zhang et al. 1998). Because M dm2 binds to p53 through its amino-terminal domain, ARF can enter into ternary complexes with both $\mathrm{Mdm} 2$ and p53.

Although human p14 ${ }^{\mathrm{ARF}}$ appears not to interact with p53 directly (Pomerantz et al. 1998; Stott et al. 1998; Zhang et al. 1998), there is some evidence that the mouse ARF protein can bind to p53 even in the absence of M dm2 (Kamijo et al. 1998). For example, in electrophoretic mobility shift assays performed with purified, activated p53 and a label ed ol igonucleotide containing tandem p53 consensus DNA-binding sites from the 
p21 ${ }^{\text {Cipl }}$ promoter, addition of recombinant p19ARF retarded the mobility of the p53-oligonucleotide complexes. In these assays, the otherwise latent DN A-binding capability of p53 needed to be activated by antibodies directed to a carboxy-terminal p53 epitope, and p19ARF was unable to substitute for the antibody in activating DNA binding. These observations raise the possibility that interactions between $\mathrm{p} 19^{\mathrm{ARF}}$ and $\mathrm{p} 53$ can occur on chromatin, al though there is no direct evidence that ARF plays any physiologic role as a p53 coactivator.

ARF requires p53 to induce growth arrest, but the direct physical interactions among p19ARF, p53, and $\mathrm{Mdm} 2$ in various binary and ternary complexes suggest that some p53 functions may reciprocally depend on ARF. Overexpression of $p 19^{A R F}$ in ARF-null NIH-3T 3 cells induced expression of a $\mathrm{p} 21^{\mathrm{Cip} 1}$ promoter-driven reporter gene in a manner that depended on endogenous p53. Paradoxically, ectopic overexpression of wild-type p53 itself in ARF-null cells did not activate the reporter, indicating that simple increases in the amount of p53 were insufficient to activate transcription in this setting. p53-Dependent reporter gene expression was restored when subliminal amounts of ARF expression vector were reintroduced together with increasing concentrations of $\mathrm{p} 53$, so $\mathrm{p} 19^{\mathrm{ARF}}$ can provide some type of activating signal that facilitates p53-dependent transcription (Kamijo et al. 1998). In this respect, the functions of p53 and p19ARF are interdependent.

Zhang and colleagues (1998) reported that ARF accelerated M dm2 turnover in HeLa cells cotransfected with vectors encoding $A R F$ and $M d m 2$. They proposed that destabilization of $\mathrm{Mdm} 2$ by ARF was the mechanism underlying p53 accumulation. However, experiments by others have yielded conflicting results. The idea that ARF destabilizes $M d m 2$ seems to be at odds with observations that ARF activation in MEFs induces endogenous $\mathrm{Mdm} 2$ to accumulate in a p53-dependent manner (de Stanchina et al. 1998; Kamijo et al. 1998; Zindy et al. 1998). Stott and coworkers (1998) confirmed that in a variety of cell types cotransfected with $\mathrm{Mdm} 2$ and p53, introduction of ARF overcame the ability of $\mathrm{Mdm} 2$ to induce p53 degradation. However, in the presence or absence of exogenous p53, ARF caused Mdm2 to accumulate. M oreover, coexpression of the $\mathrm{E} 6$ protein of human papill oma virus 16, which independently targets p53 for degradation, did not interfere with the ability of ARF to stabilize cotransfected $\mathrm{Mdm}$ 2. Minimally, it seems reasonable to conclude that ARF can antagonize $\mathrm{Mdm} 2$ function through a mechanism that does not depend on increased Mdm2 turnover.

How, then, does ARF stabilize p53? One possibility is that ARF interferes with Mdm2's ability to trigger p53 polyubiquitination. Supporting this idea, Mdm2 seems to induce the appearance of polyubiquitinated forms of p53, which are much less abundant in cells that overexpress p19ARF (Pomerantz et al. 1998). M dm2 and p19ARF also colocalize in the nucleoli of cells transfected with both genes (Pomerantz et al. 1998). Because p53 degradation depends upon its Mdm2-mediated nuclear export (Roth et al. 1998), ARF could conceivably retain Mdm2- p53 complexes in the nucleolus, preventing their degradation in the cytoplasm.

Finally, in cells lacking p53, ARF levels are significantly el evated (Quel le et al. 1995; Stott et al . 1998), but reintroduction of wild-type p53 into p53-null MEFs can restore p19ARF to normal levels (Kamijo et al. 1998). Similarly, in human Saos-2 osteosarcoma cells lacking endogenous p53 function, expression of p14 ${ }^{\mathrm{ARF}}$ was down-regulated when cells were induced to express either tetracycline-regulated or temperature-sensitive p53 (Stott et al. 1998). Therefore, not only can ARF stabilize p53, but ARF expression is in turn controlled by p53 through negative feedback. Again, the underlying mechanism needs to be clarified. Among the possibilities is that the ARF gene might be repressed by $p 53$, or the ARF protein could itself be a target of $\mathrm{Mdm} 2$-induced turnover.

\section{Oncogenic signals induce ARF}

The fact that ARF-null MEFs grow as established cell lines and can be transformed by oncogenic ras mimics effects induced by so-called immortalizing oncogenes, like myc and E1A (Land et al. 1983; Ruley 1983). It therefore seems paradoxical that myc and E1A are al so potent inducers of apoptosis (Askew et al. 1991; White et al. 1991; Evan et al. 1992; Rao et al. 1992), a process aggravated by depriving M EFs of serum survival factors (Evan et al. 1992; Lowe et al. 1993). These contrasting outcomes of Myc and E1A action-extended life versus accel erated death-can be reconciled by observations that their overexpression provides a strong sel ective pressure for events that dismantle apoptotic signaling pathways, with ARF being a key target.

Overexpression of $\mathrm{Myc}, \mathrm{E} 1 \mathrm{~A}$, or E2F-1 in primary $M E F s$ rapidly induces ARF gene expression and leads to p53-dependent apoptosis. However, ARF-null and p53null MEFs resist these effects (de Stanchina et al. 1998; Zindy et al . 1998). Similarly, wild-type or ARF hemizygous MEFs that survive Myc overexpression generally sustain either p53 mutation or ARF loss, but not both, rapidly yiel ding establ ished cell lines that tol erate supraphysiologic $M y c$ levels even in the absence of survival factors (Zindy et al. 1998). Myc and E1A can induce p53 through both ARF-dependent and ARF-independent pathways, but much higher levels of oncoprotein expression are required to activate p53 when ARF is absent. Under the latter conditions, the p53 response is attenuated and cells resistant to oncogene-induced killing rapidly emerge. Reintroduction of $\mathrm{p} 19^{\mathrm{ARF}}$ into surviving ARF-null cells expressing either $M$ yc or E1A resensitizes them to apoptosis, indicating that the attenuation of death is a direct consequence of ARF loss and does not result from other cryptic mutations. Therefore, $\mathrm{Myc}$, E1A, and E2F-1 trigger a p53-dependent oncogene checkpoint gated by ARF (Fig. 1). Although the ARF-p53 pathway is not essential for normal proliferation, the checkpoint could providea fail-safe function during embryonic development. For example, in a model of the developing 
murine lens, Rb deficiency triggers apoptosis in a p53dependent manner (Morgenbesser et al. 1994), but the process is attenuated in lenses from animals lacking INK4a/ARF (Pomerantz et al. 1998).

One component of the E1A response involves its ability to activate p300, a coactivator required for $p 53-d e-$ pendent mdm2 transcription (Thomas and White 1998). But the ability of E1A to induce ARF in MEFs is likely mediated by the E2Fs, as E1A mutants that bind p300 but do not interact with $\mathrm{Rb}$ are highly defective in this regard (de Stanchina et al. 1998) (Fig. 1). Conditional expression of E2F-1 in Saos-2 cells was followed temporally by increased ARF mRNA and protein expression (Bates et al. 1998). Cotransfection experiments indicated that wild-type E2F-1 activated transcription from a minimal ARF promoter, whereas an E2F-1 mutant defective in transactivation was devoid of activity. Despite the fact that Myc al so induces p19ARF to accumulate very rapidly (Zindy et al. 1998), it is presently unclear whether M yc activates the ARF promoter directly.

Cooperation between myc and oncogenic ras (Land et al. 1983; Ruley 1983) can be viewed to involve the ARFp53 pathway indirectly. Cultured M EFs achieve replicative immortal ity by inactivating ARF or p53, and by promoting cell death, oncogenes such as E1A and myc provide a strong sel ective pressure for disabling ARF or p53 function. Because enforced expression of p19ARF arrests wild-type MEFs but does not kill them (Quelle et al. 1995), other functions of Myc and ElA in addition to ARF induction are required for this process. The growth promoting properties of Myc and ElA are important because without them, the selection for immortal cells would likely not occur. This is even more obvious in other cell types in which transformation and tumorigenesis strongly depend upon M yc's growth promoting functions even in the absence of p53 (see, for example, M etz et al. 1995). In turn, Myc and E1A seem to inactivate cellular responses that are normally required for Rasmediated inhibition of cell proliferation, thereby converting ras into a growth-promoting gene (Franza et al . 1986; Hicks et al. 1991; Hirakawa et al. 1991; Lloyd et al. 1997; Serrano et al. 1997). The fact that oncogenic ras alone can transform MEFs lacking ARF or p53 argues that thei $r$ inactivation is key.

Because p19ARF addresses p53 through a pathway that is distinct from those activated by DNA damage (Fig. 1), induction of ARF by oncogenes may sensitize cells to the effects of genotoxic drugs that are used to treat cancer. Indeed, MEFs expressing E1A are significantly more sensitive to killing by adriamycin than their normal counterparts, whereas E1A-expressing ARF-null MEFs no longer manifest this synergy (de Stanchina et al. 1998). The ability of ARF to sense hyperproliferative stimuli must be important in tumor surveillance, because ARF I oss strongly predisposes to spontaneous cancer development and accelerates the frequency of tumor induction by irradiation or carcinogens (Serrano et al . 1996; Kamijo et al. 1997). Indeed, in the absence of ARF emergence of p53-negative tumor cells that are resistant to DN A damaging agents should still occur (Fig. 1).

\section{ARF in human cancer}

Much of the experimental work on ARF to date has involved murine systems. Senescence (and conversely, immortalization) of human cells is likely to be subject to additional and more stringent controls, particularly in light of our longer life span. Whereas p53 and Rb inactivation can endow human fibroblasts with increased proliferative potential, cells lacking these functions are not immortal, and chromosomal telomere shortening soon limits continued cell proliferation (Bodnar et al. 1998). In contrast, mouse chromosomes have much longer telomeres, and mice lacking telomerase activity must be bred through many generations before the deleterious effects of telomere shortening are manifest (Blasco et al. 1997; Lee et al. 1998).

Despite fundamental differences of this type, ARF is likely to function as a tumor suppressor in humans. Certain cancers such as melanomas, biliary tumors, nonsmall cell lung carcinomas, pancreatic, and esophageal carcinomas frequently sustain INK4a point mutations. Other tumor types, however, such as T- and B-cell acute Iymphoblastic leukemias, bladder and nasopharyngeal carcinomas, mesotheliomas, anaplastic astrocytomas, and glioblastoma multiforme routinely exhibit INK4a/ ARF deletions rather than point mutations (Ruas and Peters 1998). Whether or not these homozygous deletions target both ARF and INK4a or ARF alone, their high frequency of occurrence strongly argues that ARF loss contributes significantly to human cancer. This makes good sense. If p53 is directly targeted in $>50 \%$ of human malignancies, then p53-positive tumors have likely sustained epistatic mutations such as Mdm2 amplification or ARF Ioss. The concept that ARF monitors proliferative signals rather than DNA damage helps to expand our understanding of p53 action and provides a further rationale for ARF inactivation through chromosomal deletion in many forms of cancer.

\section{Acknowledgments}

I thank Martine F. Roussel, John Cleveland, Gerry Zambetti, Tom Curran, A. Thomas Look, Suzy Baker, Peter McKinnon, Scott W. Lowe, Ron DePinho, Tyler Jacks, Manuel Serrano, and Terry Van Dyke for stimulating and helpful discussions, and Dawn Quelle, Frederique Zindy, Takehiko Kamijo, Jason Weber, and $M$ angeng $C$ heng for contributing critical data pertinent to the work from the Sherr and Roussel laboratories. C.J.S. is an investigator of the Howard Hughes Medical Institute and also acknowledges support from the American Lebanese Syrian Associated Charities (ALSAC) of St. Jude Children's Research Hospital.

\section{References}

Askew, D.S., R.A. Ashmun, B.C. Simmons, and J.L. Cleveland. 1991. Constitutive c-myc expression in an IL3-dependent myeloid cell line suppresses cell cycle arrest and accel erates apoptosis. Oncogene 6: 1915-1922. 
Barak, Y., T. Juven, R. Haffner, and M. Oren. 1993. M dm2 expression is induced by wild type p53 activity. EMBO J. 12: 461-468.

Bates, S., A.C. Phillips, P. Clarke, F. Stott, G. Peters, R.L. Ludwig, and K.H. Vousden. 1998. E2F-1 regulation of p14 ${ }^{\text {ARF }}$ links pRB and p53. Nature (in press).

Blasco, M.A., H.-W. Lee, M .P. Hande, E. Samper, P.M . Lansdorp, R.A. DePinho, and C.W. Greider. 1997. Telomere shortening and tumor formation by mouse cells lacking telomerase RN A. Cell 91: 25-34.

Bodnar, A.G., M. Ouellette, M. Frolkis, S.E. Holt, C.-P. Chiu, G.B. Morin, C.B. Harley, J.B. Shay, S. Lichsteiner, and W.E. Wright. 1998. Extension of life-span by introduction of tel omerase into normal human cells. Science 279: 349-352.

Clarke, A.R., C.A. Purdie, D.J. Harrison, R.G. Morris, C.C. Bird, M.L. Hooper, and A.H. Wyllie. 1993. Thymocyte apoptosis induced by $\mathrm{p} 53$-dependent and independent pathways. Nature 362: 849-852.

de Stanchina, E., M.E. McCurrach, F. Zindy, S.-Y. Shieh, G. Ferbeyre, A.V. Samuelson, C. Prives, M.F. Roussel, C.J. Sherr, and S.W. Lowe. 1998. E1A signaling to p53 involves the p19ARF tumor suppressor. Genes \& Dev. 12: 2435-2443.

Demers, G.W., S.A. Foster, C.L. Hal bert, and D.A. Galloway. 1994. Growth arrest by induction of p53 in DNA damaged keratinocytes is bypassed by human papillomavirus 16 E7. Proc. Natl. Acad. Sci. 91: 4382-4386.

Duro, D., O. Bernard, V. Della Valle, R. Berger, and C.-J. Larsen. 1995. A new type of $\mathrm{p} 16^{\mathrm{INK} K / \mathrm{MTS1}}$ gene transcript expressed in B-cell malignancies. Oncogene 11: 21-29.

Dyson, N . 1998. The regulation of E2F by pRb-family members. Genes \& Dev. 12: 2245-2262.

El-Deiry, W.S., T. Tokino, V.E. Velculescu, D.B. Levy, R. Parsons, J.M. Trent, D. Lin, E. Mercer, K.W. Kinzler, and B. Vogelstein. 1993. WAF1, a potential mediator of p53 tumor suppression. Cell 75: 817-825.

Evan, G.I., A.H. Wyllie, C.S. Gilbert, T.D. Littlewood, H. Land, M. Brooks, C.M. Water, L.Z. Penn, and D.C. Hancock. 1992. Induction of apoptosis in fibroblasts by c-myc protein. Cell 69: 119-128.

Franza, B.R., K. M aruyama, J.I. Garrels, and H.E. Ruley. 1986. In vitro establishment is not sufficient prerequisite for transformation by activated ras oncogene. Cell 44: 409-418.

Fukusawa, K., T. Choi, R. Kuriyama, S. Rulong, and G.F. Vande Woude. 1996. A bnormal centrosome amplification in the absence of p53. Science 271: 1744-1747.

Giaccia, A.J. and M.B. Kastan. 1998. The complexity of p53 modulation: Emerging patterns from divergent signals. Genes \& Dev. 12: (this issue).

Gruis, N.A., P.A. van der Velden, L.A. Sandkuijl, D.E. Prins, J. Weaver-Feldhaus, A. Kamb, W. Bergman, and R. Frants. 1995. Homozygotes for CDKN 2 (p16) germline mutation in Dutch familial melanoma kindreds. Nat. Genet. 10: 351353.

Gual berto, A., K. Aldape, K. Kozakiewicz, and T.D. TIsty. 1998. An oncogenic form of p53 confers a dominant, gain-of-function phenotype that disrupts spindle checkpoint control. Proc. Natl. Acad. Sci. 95: 5166-5171.

Harper, J.W., G.R. Adami, N. Wei, K. Keyomarsi, and S.J. Elledge. 1993. The p21 cdk-interacting protein Cip1 is a potent inhibitor of G1 cyclin-dependent kinases. Cell 75: 805816.

Harvey, D.M . and A.J. Levine. 1991. p53 alteration is a common event in the spontaneous immortalization of primary BALB/c murine embryo fibroblasts. Genes \& Dev. 5: 23752385.

Harvey, M., A.T. Sands, R.S. Weiss, M.E. Hegi, R.W. Wiseman,
P. Pantazis, B.C. Giovanella, M.A. Tainsky, A. Bradley, and L.A. Donehower. 1993. In vitro growth characteristics of embryo fibroblasts isolated from p53-deficient mice. Oncogene 8: 2457-2467.

Haupt, Y., R. Maya, A. Kazaz, and M. Oren. 1997. Mdm2 promotes the rapid degradation of p53. Nature 387: 296-299.

Hermeking, $\mathrm{H}$. and D. Eick. 1994. M ediation of c-M yc-induced apoptosis by p53. Science 265: 2091-2093.

Hermeking, H., C. Lengauer, K. Polyak, T.-C. He, L. Zhang, S. Thiagalingam, K.W. Kinzler, and B. Vogelstein. 1997. 14-3$3 \sigma$ is a p53-regulated inhibitor of G2/M progression. Mol. Cell 1: 3-11.

Hicks, G.C., S.E. Egan, A.H. Greenberg, and M. Mowat. 1991. Mutant p53 tumor suppressor allel es rel ease ras-induced cell cycle growth arrest. Mol. Cell. Biol. 11: 1344-1352.

Hirakawa, T. and H.E. Ruley. 1991. Rescue of cells from ras oncogene-induced growth arrest by a second complementing oncogene. Proc. Natl. Acad. Sci. 85: 1519-1523.

Hollstein, M., K. Rice, M.S. Greenblatt, T. Soussi, R. Fuchs, T. Sorlie, E. Hovig, B. Smith-Sorensen, R. M ontesano, and C.C. Harris. 1994. Database of p53 gene somatic mutations in human tumors and cell lines. Nucleic Acids Res. 22: 35513555.

Honda, R., H. Tanaka, and H. Yasuda. 1997. Oncoprotein MDM 2 is a ubiquitin ligase E3 for tumor suppressor p53. FEBS Lett. 420: 25-27.

Howes, K.A., N. Ransom, D.S. Papermaster, J.G.H. Lasudry, D.M. Albert, and J.J. Windle. 1994. A poptosis or retinoblastoma: Alternative fates of photoreceptors expressing the HPV-16 E7 gene in the presence or absence of p53. Genes \& Dev. 8: 1300-1310.

Jacks, T. and R.A. Weinberg. 1996. Cell-cycle control and its watchman. Nature 381: 643-644.

Kamb, A., N .A. Gruis, J. Weaver-Fel dhaus, Q. Liu, K. Harshman, S.V. Tavtigian, E. Stockert, R.S. Day, III, B.E. Johnson, and M.H. Skolnick. 1994a. A cell cycle regulator involved in genesis of many tumor types. Science 264: 436-440.

Kamb, A., D. Shattuck-Eidens, R. Eeles, Q. Liu, N.A. Gruis, W. Ding, C. Hussey, T. Tran, Y. Miki, J. Weaver-Fel dhaus, M. McClure, J.F. Aitken, D.E. Anderson, W. Bergman, R. Frants, D.E. Goldgar, A. Green, R. MacLennan, N.G. Martin, L.J. Meyer, P. Youl, J.J. Zone, M.H. Skolnick, and L.A. CannonAlbright. 1994b. A nalysis of the p16 gene (CDKN 2) as a candidate for the chromosome $9 p$ melanoma susceptibility locus. Nature Genet. 8: 22-26.

Kamijo, T., F. Zindy, M.F. Roussel, D.E. Quelle, J.R. Downing R.A. Ashmun, G. Grosveld, and C.J. Sherr. 1997. Tumor suppression at the mouse INK4a locus mediated by the alternative reading frame product p19ARF. Cell 91: 649-659.

Kamijo, T., J.D. Weber, G. Zambetti, F. Zindy, M.F. Roussel, and C.J. Sherr. 1998. Functional and physical interactions of the ARF tumor suppressor with p53 and M dm2. Proc. Natl. Acad. Sci. 95: 8292-8297.

Kastan, M.B., O. Onyekwere, D. Sidransky, B. Vogelstein, and R.W. Craig. 1991. Participation of p53 protein in the cellular response to DN A damage. Cancer Res. 51: 6304-6311.

Kastan, M.B., Q. Zhan, W.S. El-Deiry, F. Carrier, T. Jacks, W.V. Walsh, B.S. Plunkett, B. Vogelstein, and A.J. Fornace, Jr. 1992. A mammalian cell cycle checkpoint pathway utilizing p53 and GADD45 is defective in ataxia-telangiectasia. Cell 71: 587-597.

Ko, L.J. and C. Prives. 1996. p53: Puzzle and paradigm. Genes \& Dev. 10: 1054-1072.

Kubbutat, M.H., S.N. Jones, and K.H. Vousden. 1997. Regulation of p53 stability by $\mathrm{Mdm}$ 2. Nature 387: 299-303.

Kuerbitz, S.J., B.S. Plunkett, W.V. Walsh, and M .B. Kastan. 1992. 
Wild-type p53 is a cell cycle checkpoint determinant following irradiation. Proc. Natl. Acad. Sci. 89: 7491-7495.

Land, H., L.F. Parada, and R.A. Weinberg. 1983. Tumorigenic conversion of primary embryo fibroblasts requires at least two cooperating oncogenes. Nature 304: 596-602.

Lanni, J.S. and T. Jacks. 1998. Characterization of the p53-dependent postmitotic checkpoint following spindle disruption. Mol. Cell. Biol. 18: 1055-1064.

Lee, H.-W., M.A. Blasco, G.J. Gottlieb, J.W. Horber, C.W. Gre ider, and R.A. DePinho. 1998. Essential role of mouse tel omerase in highly proliferative organs. Nature 392: 569-574.

Levine, A.J. 1997. p53, the cellular gatekeeper for growth and division. Cell 88: 323-331.

Livingstone, L.R., A. White, J. Sprouse, E. Livanos, T. Jacks, and T.D. TIsty. 1992. Altered cell cycle arrest and gene amplification potential accompany loss of wild-type p53. Cell 70: 923-935.

Lloyd, A.C., F. Obermuller, S. Staddon, C.F. Barth, M. McMahon, and $\mathrm{H}$. Land. 1997. Cooperating oncogenes converge to regulate cyclin/cdk complexes. Genes \& Dev. 11: 663-667.

Lowe, S.W. and H.E. Ruley. 1993. Stabilization of the p53 tumor suppressor is induced by adenovirus- $5 \mathrm{E} 1 \mathrm{~A}$ and accompanies apoptosis. Genes \& Dev. 7: 535-545.

Lowe, S.W., H.E. Ruley, T. Jacks, and D.E. Housman. 1993. p53-dependent apoptosis modulates the cytotoxicity of anticancer agents. Cell 74: 957-966.

Mao, L., A. Merlo, G. Bedi, G.I. Shapiro, C.D. Edwards, B.J. Rollins, and D. Sidransky. 1995. A novel p16 ${ }^{\text {IN K4a }}$ transcript. Cancer Res. 55: 2995-2997.

Metz, T., A.W. Harris, and J.M. Adams. 1995. Absence of p53 allows direct immortalization of hematopoietic cells by the myc and raf oncogenes. Cell 82: 29-36.

M orgenbesser, S.D., B.O. Williams, T. Jacks, and R.A. DePinho. 1994. p53-dependent apoptosis produced by Rb-deficiency in the developing mouse lens. Nature 371: 72-74.

Pan, H. and A.E. Griep. 1994. Altered cell cycle regulation in the lens of HPV-16 E6 or E7 transgenic mice: Implications for tumor suppressor gene function in development. Genes \& Dev. 8: 1285-1299.

Paulovich, A.G., D.P. Toczyski, and L.H. Hartwell. 1997. When checkpoints fail. Cell 88: 315-321.

Pomerantz, J., N . Schrei ber-Agus, N .J. Liégeois, A. Silverman, L. Alland, L. Chin, J. Potes, K. Chen, I. Orlow, H.-W. Lee, C. Cordon-Cardo, and R. DePinho. 1998. The Ink4a tumor suppressor gene product, p19ARF, interacts with MDM2 and neutralizes MDM 2's inhibition of p53. Cell 92: 713-723.

Qin, X.Q., D.M. Livingston, W.G. Kaelin, Jr., and P.D. Adams. 1994. Deregulated transcription factor E2F-1 expression leads to S-phase entry and p53-mediated apoptosis. Proc. Natl. Acad. Sci. 91: 10918-19022.

Quelle, D.E., F. Zindy, R.A. Ashmun, and C.J. Sherr. 1995. Alternative reading frames of the IN K4a tumor suppressor gene encode two unrel ated proteins capable of inducing cell cycle arrest. Cell 83: 993-1000.

Quelle, D.E., M. Cheng, R.A. Ashmun, and C.J. Sherr. 1997. Cancer-associated mutations at the INK4a locus cancel cell cycle arrest by $\mathrm{p} 16^{\mathrm{INK} 4 a}$ but not by the alternative reading frame protein p19ARF. Proc. Natl. Acad. Sci. 94: 3436-3440.

Rao, L., M. Debbas, P. Sabbatini, D. Hockenberry, S. Korsmeyer, and E. White. 1992. The adenovirus E1A proteins induce apoptosis which is inhibited by E1B 19K and Bcl-2 proteins. Proc. Natl. Acad. Sci. 89: 7742-7746.

Roth, J., M. Dobbelstein, D. Freedman, T. Shenk, and A.J. Levine. 1998. N ucleo-cytoplasmic shuttling of the hdm 2 oncoprotein regulates the levels of the p53 protein via a pathway used by the human immunodeficiency virus rev protein.
EMBO J. 17: 554-564.

Ruas, M. and G. Peters. 1998. The $\mathrm{p} 16^{\mathrm{INK} 4 \mathrm{a}} / \mathrm{CDKN} 2 \mathrm{~A}$ tumor suppressor and its relatives. Biochim. Biophys. Acta Rev. Cancer (in press).

Ruley, H.E. 1983. Adenovirus early region $1 \mathrm{~A}$ enables viral and cellular transforming genes to transform primary cells in culture. Nature 304: 602-606.

Serrano, M., G.J. Hannon, and D. Beach. 1993. A new regulatory motif in cell cycle control causing specific inhibition of cyclin D/CDK4. Nature 366: 704-707.

Serrano, M., H.-W. Lee, L. Chin, C. Cordon-Cardo, D. Beach, and R.A. DePinho. 1996. Role of the INK4a locus in tumor suppression and cell mortality. Cell 85: 27-37.

Serrano, M., A.W. Lin, M.E. McCurrach, D. Beach, and S.W. Lowe. 1997. Oncogenic ras provokes premature cell senescence associated with accumulation of p53 and p16 $6^{\text {IN K4a }}$. Cell 88: 593-602.

Shan, B. and W.-H. Lee. 1994. Deregulated expression of E2F-1 induces S-phase entry and leads to apoptosis. Mol. Cell. Biol. 14: 8166-8173.

Sherr, C.J. 1996. Cancer cell cycles. Science 274: 1672-1677.

Slebos, R.J.C., M.H. Lee, B.S. Plunkett, T.D. Kessis, B.O. Williams, T. Jacks, L. Hedrick, M.B. Kastan, and K.R. Cho. 1994. p53-dependent G1 arrest involves pRB-related proteins and is disrupted by the human papillomavirus 16 E7 oncoprotein. Proc. Natl. Acad. Sci. 91: 5320-5324.

Stone, S., P. Jiang, P. Dayananth, S.V. Tavtigian, H. Katcher, D. Parry, G. Peters, and A. Kamb. 1995. Complex structure and regulation of the p16(MTS1) locus. Cancer Res. 55: 29882994.

Stott, F., S.A. Bates, M. James, B.B. McConnell, M. Starborg, S. Brookes, I. Palmero, E. Hara, K.H. Vousden, and G. Peters. 1998. The alternative product from the human CDKN 2A locus, p14 ${ }^{A R F}$, partici pates in a regulatory feedback loop with p53 and MDM2. EMBO J. (in press).

Swafford, D.S., S.K. Middleton, W.A. Palmisano, K.J. Nikula, J. Tesfai gzi, S.B. Baylin, J.G. Herman, and S.A. Belinsky. 1997. Frequent aberrant methylation of $\mathrm{p} 16^{\mathrm{INK} 4 \mathrm{a}}$ in primary rat lung tumors. Mol. Cell. Biol. 17: 1366-1374.

Symonds, H., L. Krall, L. Remington, M. Saenz-Robles, S. Lowe, T. Jacks, and T. Van Dyke. 1994. p53-dependent apoptosis suppresses tumor growth and progression in vivo. Cell 78: 703-711.

Thomas, A. and E. White. 1998. Suppression of the p300-dependent $\mathrm{mdm} 2$ negative-feedback loop induces the p53 apoptotic function. Genes \& Dev. 12: 1975-1985.

Van Dyke, T. 1994. Analysis of viral-host protein interactions and tumorigenesis in transgenic mice. Semin. Cancer Biol. 5: 47-60.

Wagner, A.J., J.M. Kokontis, and N. Hay. 1994. Myc-mediated apoptosis requires wild-type p53 in a manner independent of cell cycle arrest and the ability of p53 to induce p21 waf1/ cip1. Genes \& Dev. 8: 2817-2830.

Weinberg, R.A. 1995. The retinoblastoma protein and cell cycle control. Cell 81: 323-330.

- - - 1997. The cat and mouse games that genes, viruses, and cells play. Cell 88: 573-575.

White, E. 1996. Life, death, and the pursuit of apoptosis. Genes \& Dev. 10: 1-15.

White, E., R. Cipriani, P. Sabbatini, and A. Denton. 1991. The adenovirus E1B 19-kilodalton protein overcomes the cytotoxicity of E1A proteins. J. Virol. 65: 2968-2978.

$\mathrm{Wu}, \mathrm{X}$. and A.J. Levine. 1994. p53 and E2F-1 cooperate to mediate apoptosis. Proc. Natl. Acad. Sci. 91: 3602-3606.

Wu, X., J.H. Bayle, D. Olson, and A.J. Levine. 1993. The p53mdm-2 autoregulatory feedback loop. Genes \& Dev. 7: 
1126-1132.

Xiong, Y., G.J. Hannon, H. Zhang, D. Casso, R. Kobayashi, and D. Beach. 1993. p21 is a universal inhibitor of cyclin kinases. Nature 366: 701-704.

Yin, Y., M.A. Tainsky, F.Z. Bischoff, L.C. Strong, and G.M. Wahl. 1992. Wild-type p53 restores cell cycle control and inhibits gene amplification in cells with mutant p53 alleles. Cell 70: 937-948.

Zhang, Y., Y. Xiong, and W.G. Yarbrough. 1998. ARF promotes M DM 2 degradation and stabilizes p53: ARF-INK4a locus deletion impairs both the Rb and p53 tumor suppressor pathways. Cell 92: 725-734.

Zindy, F., C.M. Eischen, D. Randle, T. Kamijo, J.L. Cleveland, C.J. Sherr, and M.F. Roussel. 1998. Myc signaling via the ARF tumor suppressor regulates p53-dependent apoptosis and immortalization. Genes \& Dev. 12: 2424-2434. 


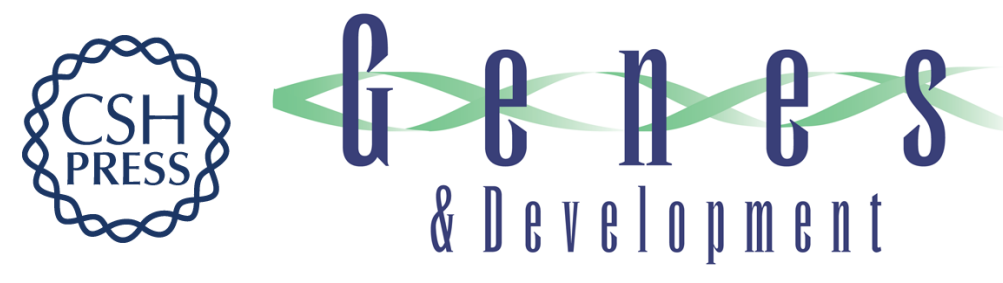

\section{Tumor surveillance via the ARF-p53 pathway}

Charles J. Sherr

Genes Dev. 1998, 12:

Access the most recent version at doi:10.1101/gad.12.19.2984

References This article cites 76 articles, 35 of which can be accessed free at: http://genesdev.cshlp.org/content/12/19/2984.full.html\#ref-list-1

License

Email Alerting Receive free email alerts when new articles cite this article - sign up in the box at the top Service right corner of the article or click here.

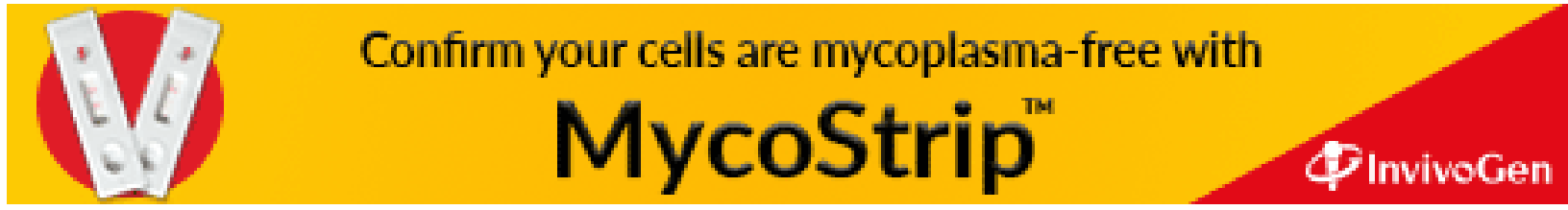

